\title{
Article \\ Digital Addiction: Systematic Review of Computer Game Addiction Impact on Adolescent Physical Health
}

\author{
Norshakirah Aziz $^{1, *}$, Md Jan Nordin ${ }^{2}$, Said Jadid Abdulkadir ${ }^{1}$ (D) and Muhammad Muhaimin M. Salih ${ }^{1}$ \\ 1 Centre for Research in Data Science (CeRDaS), Computer Information Science Department, Universiti \\ Teknologi PETRONAS, Seri Iskandar 32610, Perak, Malaysia; saidjadid.a@utp.edu.my (S.J.A.); \\ muhaiminamin777@gmail.com (M.M.M.S.) \\ 2 Center for Artificial Intelligence Technology (CAIT), Faculty of Information Science and Technology, \\ Universiti Kebangsaan Malaysia, Bangi 43600, Selangor, Malaysia; jan@ukm.edu.my \\ * Correspondence: norshakirah.aziz@utp.edu.my
}

check for updates

Citation: Aziz, N.; Nordin, M.J.;

Abdulkadir, S.J.; Salih, M.M.M.

Digital Addiction: Systematic Review of Computer Game Addiction Impact on Adolescent Physical Health.

Electronics 2021, 10, 996. https://

doi.org/10.3390/electronics10090996

Academic Editor: Luca Mesin

Received: 28 February 2021

Accepted: 26 March 2021

Published: 22 April 2021

Publisher's Note: MDPI stays neutral with regard to jurisdictional claims in published maps and institutional affiliations.

Copyright: (c) 2021 by the authors. Licensee MDPI, Basel, Switzerland. This article is an open access article distributed under the terms and conditions of the Creative Commons Attribution (CC BY) license (https:// creativecommons.org/licenses/by/ $4.0 /)$.

\begin{abstract}
The advancement of technology has enabled powerful microprocessors to render highquality graphics for computer gaming. Despite being intended for leisure purposes, several components of the games alongside the gamer's environmental factors have resulted in digital addiction (DA) towards computer games such as massively multiplayer online games (MMOG). Excessive gaming among adolescents has various negative impacts on an individual. However, only a few researchers have addressed the impact of DA on physical health. Thus, the primary objective of this research is to study the impact of DA on physical health among Malaysian adolescents. This study focuses on Malaysian adolescents of ages 12-18 years old who are addicted to computer games, specifically the MMOG. The methodology used for the study involves focus group discussions (FGD) and extensive literature study. The FGD sessions have involved both medical experts and game experts. The outcome of FGD discussion is recorded and justified with the existing relevant literature from high-impact journals, theses, conferences, books, and reports. This paper provides evidence of five physical health impacts of DA associated with adolescents. The factors of DA, the addiction components existing in MMOG computer games, and the DA health risk assessment are presented in the results section. Based on the study, it is concluded that DA among Malaysian adolescents can cause various impacts on physical health such as obesity, back pain, and neck pain, orthopaedic/joint muscle, eyesight problem, hearing problem, as well as physical inactivity.
\end{abstract}

Keywords: digital addiction; computer game addiction; physical health; adolescent

\section{Introduction}

Digital addiction (DA) can be described as an addiction towards listening, watching, or playing for entertainment purposes using an electronic device. According to Caplan et al. [1], DA has become a trend due to significant technological improvements in recent years. The issue of DA is highly concerning, as computer gaming has transformed from colocated experiences into a multiplayer, socially-oriented platform. The evolution of computer games has shown that the tendency of playing computer games has increased year by year. There are three types of DA - the first type is computer game and Internet addiction, the second type is social media addiction, and the third type is smartphone addiction [2]. Subsequently, researchers have come out with studies to relate DA health problems, such as mental health [3], psychology [4], physical health [5], and anxiety [6]. These studies aim to visualize correlations and to prove if DA can become a more severe and damaging issue that requires attention from various institutions, such as government, health, and education. Additionally, the research has been aimed to raise awareness on the drawbacks of excessive usage of the Internet, which needs to be controlled by many parties, such as government agencies, parents, and teachers. 


\section{Systematic Planning}

A systematic plan was conducted to understand and explain the fundamentals and the nature of the study. In this study, we have conducted an empirical user study to investigate the ways by which each DA component can affect physical health. The study aided the identification of three main components in DA. The primary focus is given to a diary analysis accompanied by interviews with medical and game experts. The findings of this study are intended to describe DA related to physical health and the initial design model for solutions for problematic and addictive digital usage.

Figure 1 visualizes the framework of the research process, which is divided into four stages. The first stage consists of the steps required for background studies and problem identification. The second stage is the systematic literature review (SLR) systematic planning stage, which consists of a series of steps to select the most relevant publication for extensive review. The third step is the focus group discussion (FGD) sessions with medical experts and gaming experts, while the last stage discusses and concludes the study's outcome.

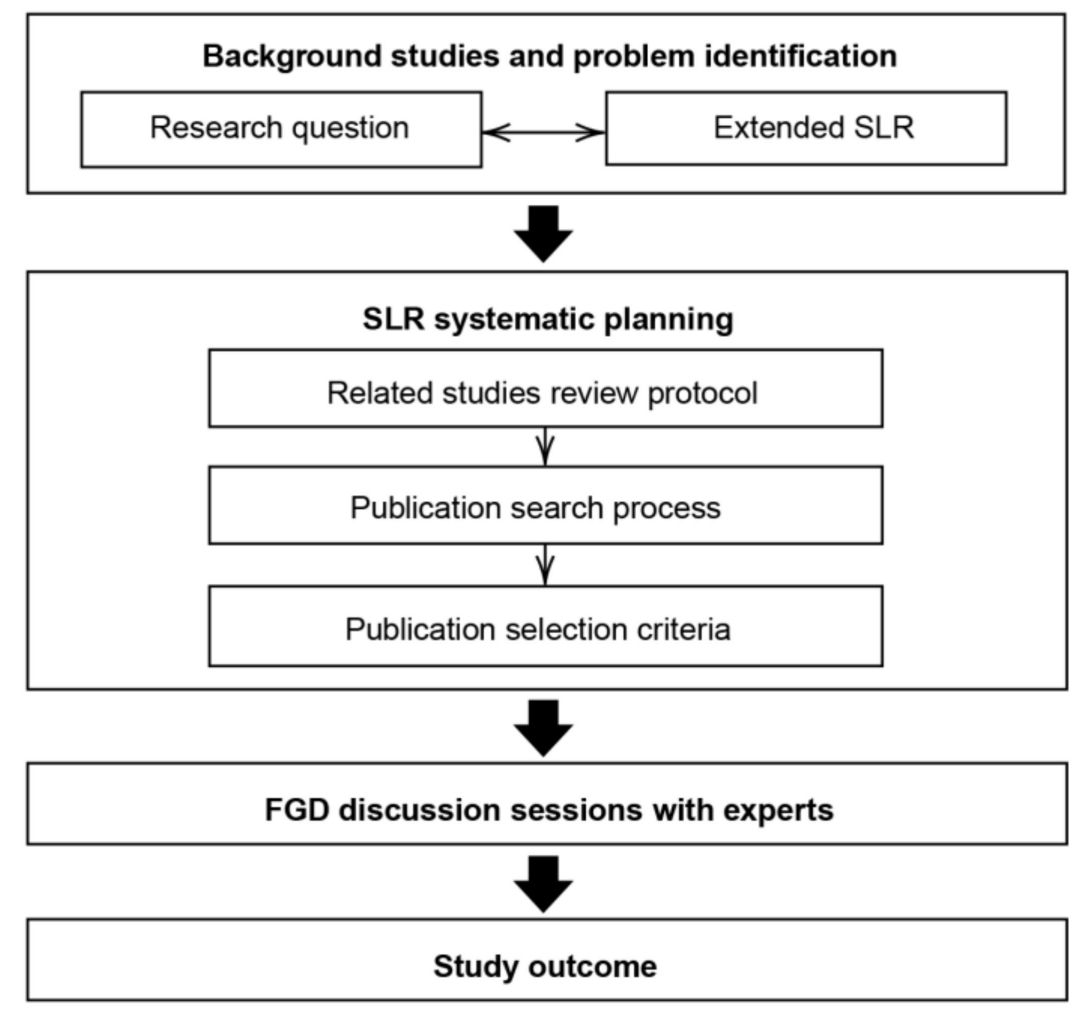

Figure 1. The research framework. SLR: systematic literature review; FGD: focus group discussion.

\section{Research Questions}

The following research questions are formulated to guide the research path and outcome. The research questions can be answered through extensive literature study and qualitative methods such as FGD. The motivations of each research question are described in Table 1.

Table 1. Research questions and motivation.

\begin{tabular}{ccc}
\hline ID & Research Question & Motivation \\
\hline RQ1 & Digital addiction (DA) & To answer research questions regarding DA. \\
\hline RQ1.0 & What is addiction? & To get a clear definition of the term “addiction" \\
\hline RQ1.1 & What is DA? & To get a clear definition of DA. \\
\hline
\end{tabular}


Table 1. Cont.

\begin{tabular}{|c|c|c|}
\hline ID & Research Question & Motivation \\
\hline RQ1.2 & What are the causes of DA? & To explore the possible causes of DA. \\
\hline RQ1.3 & How does DA impact an addict? & To explain the impact of DA on an addict. \\
\hline RQ1.4 & $\begin{array}{l}\text { How does the withdrawal of the addictive } \\
\text { substance impact an addict? }\end{array}$ & $\begin{array}{l}\text { To understand how the withdrawal of the addictive } \\
\text { substance impacts an addict. }\end{array}$ \\
\hline RQ2 & Internet Gaming Disorder (IGD) & To answer research questions regarding IGD. \\
\hline RQ2.0 & What is IGD? & To define IGD. \\
\hline RQ2.1 & $\begin{array}{l}\text { What are the causes of computer } \\
\text { game addiction? }\end{array}$ & To explore the possible cause of computer game addiction. \\
\hline $\mathrm{RQ} 2.2$ & $\begin{array}{l}\text { What are the effects of excessive computer } \\
\text { gaming/IGD? }\end{array}$ & $\begin{array}{l}\text { To explain the impact of excessive computer gaming on } \\
\text { the addict. }\end{array}$ \\
\hline RQ2.3 & Is IGD diagnosable and curable? & To explore the possible chances of curing IGD. \\
\hline RQ3 & $\begin{array}{c}\text { What are the factors of DA in computer games } \\
\text { which influence Malaysian adolescents? }\end{array}$ & $\begin{array}{l}\text { To explore the DA factors in computer games among } \\
\text { Malaysian adolescents. }\end{array}$ \\
\hline RQ4 & $\begin{array}{l}\text { What are the components of DA in computer } \\
\text { games which influence Malaysian adolescents? }\end{array}$ & $\begin{array}{l}\text { To explore the DA components among Malaysian } \\
\text { adolescents. }\end{array}$ \\
\hline RQ5 & $\begin{array}{l}\text { What are the consequences of computer game } \\
\text { addiction on adolescent physical health? }\end{array}$ & $\begin{array}{l}\text { To explore the impact of computer game addiction on the } \\
\text { physical health of an adolescent. }\end{array}$ \\
\hline
\end{tabular}

\section{Methodology}

In this study, two sources were considered which were FGD and literature study. The research has been reviewed and approved by the University through the Graduate Assistantship (GA) Scheme. Written consent has also been obtained from all FGD participants.

\subsection{Focus Group Discussion}

This study was carried out through six FGD sessions and handled by two expert groups. The first FGD group consisted of seven medical experts while the second FGD group consisted of five professional game experts.

\subsubsection{Group 1: Medical Experts}

The first FGD group consisted of medical experts who have experiences with adolescents who are computer game addicts. The medical experts had the qualification of serving in a government hospital as consultant psychiatrists for children and adolescents for at least ten years. The medical team consisted of five medical experts who were selected on the advice of the leading member of the Malaysian Government Hospital, a reputable individual and regularly awarded by the Malaysian government. The aim of the medical expert group was to form an in-depth understanding of the DA (RQ1), IGD (RQ2), DA factors (RQ3), DA components (RQ4), and consequences of DA on adolescents' physical health (RQ5). Following this, six FGD sessions were conducted throughout this study with the medical experts to reveal the answers to the research questions.

\subsubsection{Group 2: Professional Game Experts}

The second FGD group consisted of five professional gamers/experts in the computer game, with experience in playing computer games for more than ten years. The group consisted of the members of the only team that has represented Malaysia in The International DOTA 2 competition in 2017, and the team managed to finish in fourth place. The purpose of having the FGD with professional game experts was to verify and confirm the DA components (RQ4), which were identified in a preliminary study. The game experts shared their experiences of playing the MMOG computer game and joining computer 
gaming competitions. In this study, the two expert groups were responsible for describing the correlation between addiction components and their effects on Malaysian teenagers. Their responses were vital to visualize how computer gaming affects the physical health of adolescents in Malaysia (RQ5).

\subsection{Literature Search}

During the literature search, the focus scope was given to digital addiction by adapting computer game addiction as a case study. This study performed as an SLR which presented a repeatable process of gathering all existing research on a specific topic or a particular research question [7]. This type of study aims to gather, review, and evaluate the studies related to a particular area in order to provide understanding to researchers in the related field. It is conducted to reveal any research gaps within the study area, hence promoting researchers to explore the gaps and allowing greater insight within the study area [8].

\subsubsection{The Review Protocol}

The review protocol conducted followed the guidelines provided by Moher et al. [9]. This subsection addresses the database and selection (inclusion and exclusion) criteria, search strategy, publication selection, and data extraction. Specifying the methodology in advance decreases the possibility of bias being brought into the analysis.

\subsubsection{Database and Selection Criteria}

The literature sources were thoroughly searched through four credible scholarly databases, which are ScienceDirect, SpringerLink, ACM Digital Library, and IEEE Xplore. The reference lists of included studies were also consulted to locate additional references of interest. Criteria for sources inclusion and exclusion were formulated and performed to ensure the sources included were closely related and of high credibility. The inclusion and exclusion criteria are defined in Table 2.

Table 2. Inclusion and exclusion criteria.

\begin{tabular}{llll}
\hline \multicolumn{2}{c}{ Inclusion Criteria } & \multicolumn{1}{c}{ Exclusion Criteria } \\
\hline - & Published between 2016-2020 & Published before 2016 or after 2020 \\
- & Article available in full-text & Article unavailable in full-text \\
- & Pritten in the English language & Not written in the English language \\
- & Related to the RQs & Not published in the selected databases \\
& & Irrelevant to the RQs \\
\end{tabular}

\subsubsection{Search Strategy}

Table 3 presents the full electronic search strategy for the literature study.

\subsubsection{Publication Selection}

In this study, 1,116,983 scholarly articles related to the keywords "digital addiction", "computer game addiction" and "Internet game addiction" were identified. After the screening process, we compiled a total of 354,358 articles from the recent 5 years (2016-2020), allowing the analysis to use up-to-date materials. This study, however, did not limit the literature to be only from the recent 5-year period, especially when referring to the fundamental studies. Figure 2 visualizes the distribution of identified publications by year. 
Table 3. Full electronic search strategy.

\begin{tabular}{|c|c|c|}
\hline Keyword & $\begin{array}{c}\text { Database } \\
\text { (Last Retrieved) }\end{array}$ & Full Query Syntax \\
\hline \multirow{4}{*}{$\begin{array}{l}\text { Digital } \\
\text { addiction }\end{array}$} & $\begin{array}{l}\text { ScienceDirect } \\
\text { (21 Nov. 2020) }\end{array}$ & $\begin{array}{c}\text { General query: digital addiction } \\
\text { Title, abstract, keywords: "physical health" AND “adolescent" } \\
\text { Year published: 2016-2020 }\end{array}$ \\
\hline & $\begin{array}{l}\text { SpringerLink } \\
(21 \text { Nov. } 2020)\end{array}$ & $\begin{array}{c}\text { Using Advanced Search: } \\
\text { Query: }\{\text { "Digital addiction" AND (“physical health AND adolescent”)\} } \\
\text { Year published: 2016-2020 }\end{array}$ \\
\hline & $\begin{array}{c}\text { ACM DL } \\
(21 \text { Nov. 2020) }\end{array}$ & $\begin{array}{c}\text { "query": }\{\text { Title:(Digital addiction) AND Fulltext:(Digital addiction) AND } \\
\text { Fulltext:(physical health) AND Fulltext:(adolescent) }\} \\
\text { "filter": }\{\text { Publication Date: (01/01/2016 TO 12/31/2020), } \\
\text { ACM Content: DL, NOT VirtualContent: true }\}\end{array}$ \\
\hline & $\begin{array}{l}\text { IEEE Xplore } \\
\text { (21 Nov. 2020) }\end{array}$ & $\begin{array}{l}\text { General query: digital addiction } \\
\text { Filter: Selection based on title suitability }\end{array}$ \\
\hline \multirow{4}{*}{$\begin{array}{l}\text { Computer } \\
\text { game } \\
\text { addiction }\end{array}$} & $\begin{array}{l}\text { ScienceDirect } \\
(21 \text { Nov. 2020) }\end{array}$ & $\begin{array}{c}\text { General query: computer game addiction } \\
\text { Title, abstract, keywords: "physical health" AND "adolescent" } \\
\text { Year published: } 2016-2020\end{array}$ \\
\hline & $\begin{array}{l}\text { SpringerLink } \\
(21 \text { Nov. } 2020)\end{array}$ & $\begin{array}{c}\text { Using Advanced Search: } \\
\text { Query: }\{\text { “Computer game addiction" AND ("physical health AND adolescent")\} } \\
\text { Year published: 2016-2020 }\end{array}$ \\
\hline & $\begin{array}{c}\text { ACM DL } \\
(21 \text { Nov. 2020) }\end{array}$ & $\begin{array}{l}\text { "query": \{ Title:(Computer game addiction) } \\
\text { AND Fulltext:(Computer game addiction) } \\
\text { AND Fulltext:(physical health) AND Fulltext:(adolescent) \} } \\
\text { "filter": \{ Publication Date: (01/01/2016 TO 12/31/2020), } \\
\text { ACM Content: DL, NOT VirtualContent: true \} }\end{array}$ \\
\hline & $\begin{array}{l}\text { IEEE Xplore } \\
(21 \text { Nov. 2020) }\end{array}$ & $\begin{array}{l}\text { General query: computer game addiction } \\
\text { Filter: Selection based on title suitability }\end{array}$ \\
\hline \multirow{4}{*}{$\begin{array}{l}\text { Internet } \\
\text { game } \\
\text { addiction }\end{array}$} & $\begin{array}{l}\text { ScienceDirect } \\
\text { (21 Nov. 2020) }\end{array}$ & $\begin{array}{c}\text { General query: Internet game addiction } \\
\text { Title, abstract, keywords: "physical health" AND adolescent" } \\
\text { Year published: 2016-2020 }\end{array}$ \\
\hline & $\begin{array}{l}\text { SpringerLink } \\
(21 \text { Nov. 2020) }\end{array}$ & $\begin{array}{c}\text { Using Advanced Search: } \\
\text { Query: }\{\text { “Internet game addiction" AND (“physical health AND adolescent”)\} } \\
\text { Year published: } 2016-2020\end{array}$ \\
\hline & $\begin{array}{c}\text { ACM DL } \\
\text { (21 Nov. 2020) }\end{array}$ & $\begin{array}{l}\text { "query": \{ Title:(Internet game addiction) } \\
\text { AND Fulltext:(Internet game addiction) } \\
\text { AND Fulltext:(physical health) AND Fulltext:(adolescent) \} } \\
\text { "filter": }\{\text { Publication Date: (01/01/2016 TO 12/31/2020), } \\
\text { ACM Content: DL, NOT VirtualContent: true }\}\end{array}$ \\
\hline & $\begin{array}{l}\text { IEEE Xplore } \\
\text { (21 Nov. 2020) }\end{array}$ & $\begin{array}{l}\text { General query: internet game addiction } \\
\text { Filter: Selection based on title suitability }\end{array}$ \\
\hline
\end{tabular}

ACM DL: Association for Computing Machinery Digital Library.

The initial search was conducted on scholarly databases on ScienceDirect, SpringerLink, ACM, and IEEE Explore retrieving a total of 1,071,835 articles as visualized in Figure 3. Some 757,596 articles published before 2016 were removed to keep only the articles published in the recent 5-year-period in the selection criteria. In the next steps, all articles were queried using the keywords inclusion criteria, and 341 articles were selected from this process. After the process of deduplication, 97 papers were left and finally, 38 articles that had thoroughly discussed the factors of DA. 


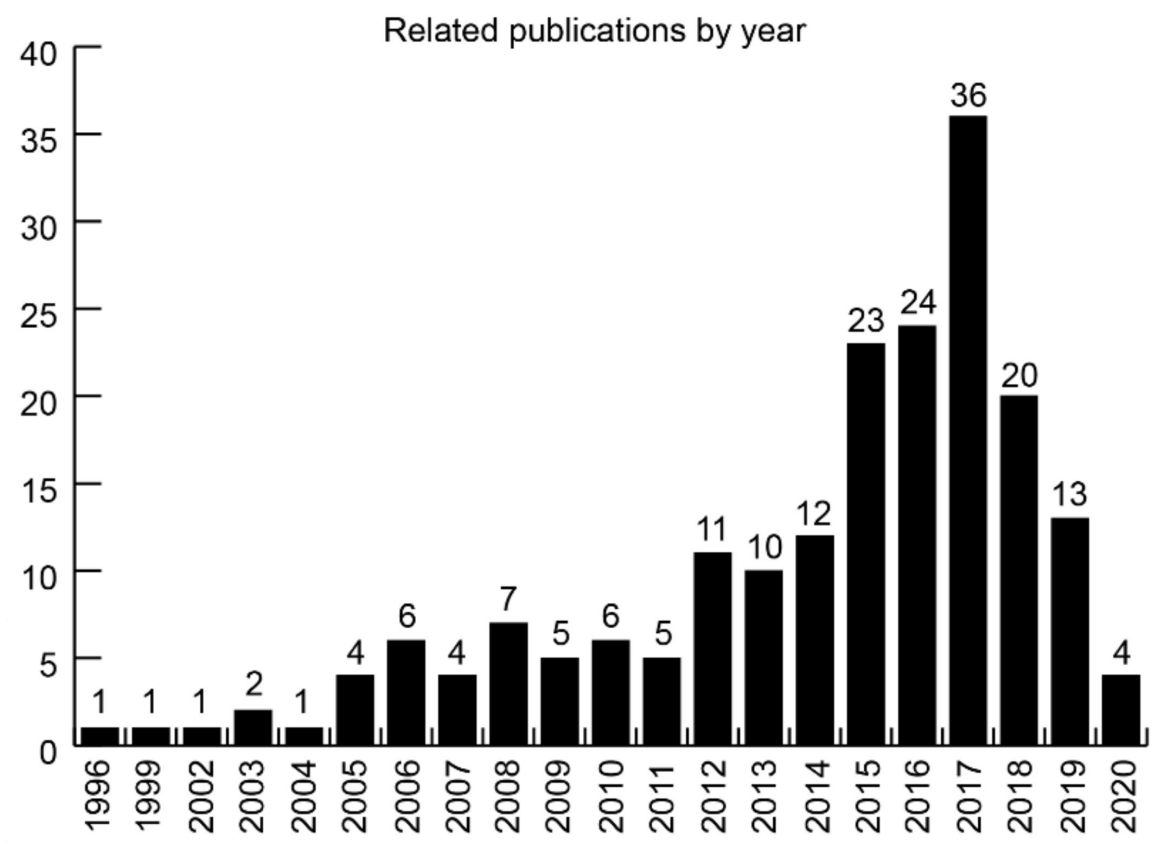

Figure 2. Identified related publications by year.

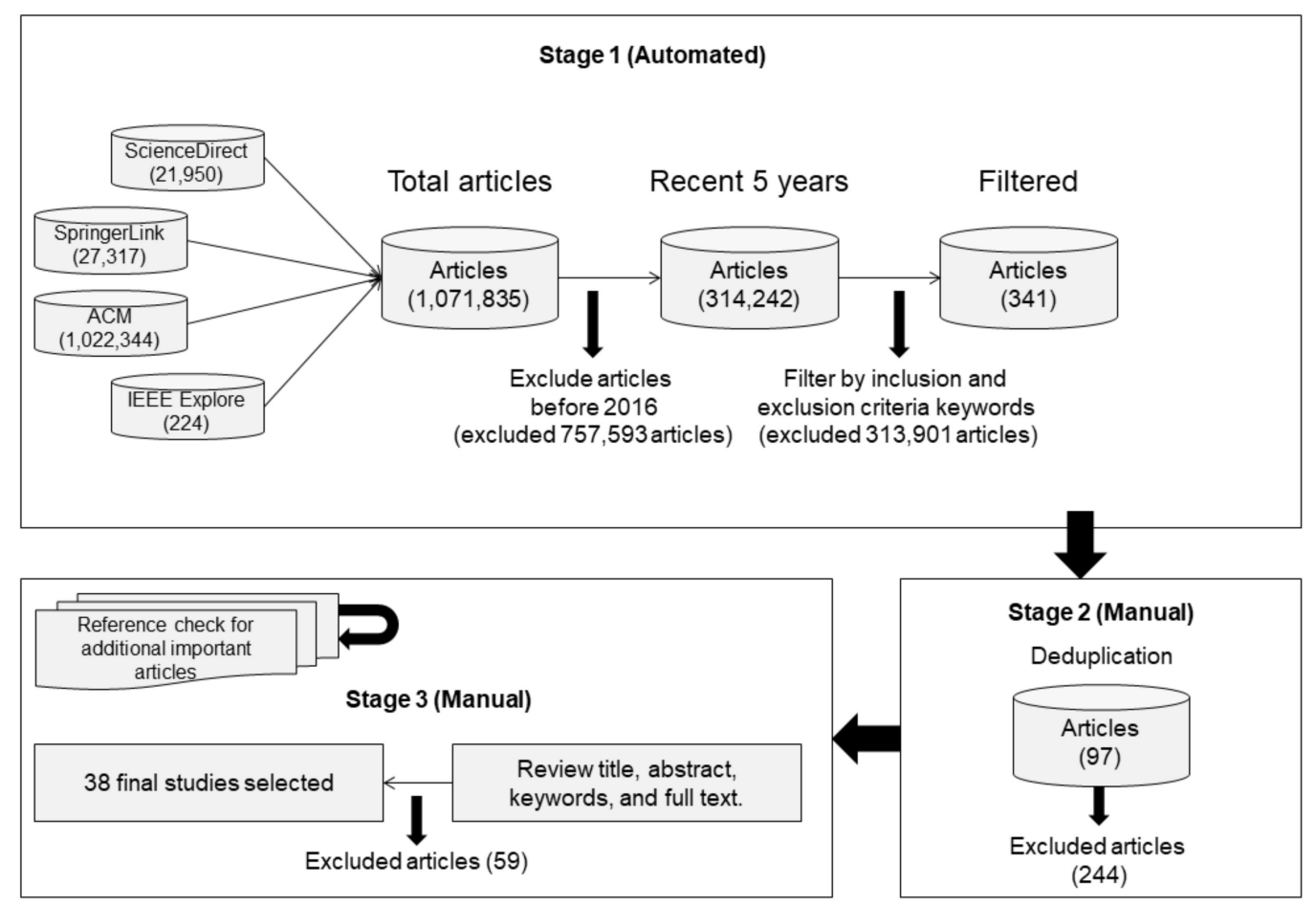

Figure 3. Publication selection process.

\subsubsection{Data Extraction}

A spreadsheet was used to record the results of database searches. Data extraction was conducted by downloading the search results from the publication database. Mendeley Desktop software was used to automatically eliminate the duplicates and manage the list of publications. Next, the papers were grouped in the software based on their similar keywords. The reference lists from the papers were consulted to locate additional references, especially the fundamental studies regarding DA. Information extracted from these 
publications included the paper title, authors, publication year, publication type (journal, thesis, conference, book, or report), and discussion (DA factors, DA components, physical health impact).

\subsubsection{Risk of Bias across Studies}

The study may be prone to interview bias and citation bias. Therefore, bias risk precautionary steps were prepared to avoid the bias as shown in Table 4.

Table 4. The method used to avoid bias.

\begin{tabular}{|c|c|}
\hline Type of Bias & Methods Used to Avoid Bias \\
\hline Interview bias & $\begin{array}{l}\text { - } \quad \text { Define the scope of questions for the FGD. } \\
\text { The FGD interview questions were carefully prepared to guide } \\
\text { the session preferably aimed to answer the RQs. }\end{array}$ \\
\hline Citation bias & $\begin{array}{l}\text { - } \quad \text { References used were selected from highly credible databases. } \\
\text { - } \quad \text { fundamental studies before the year 2016. } \\
\text { - Selected studies were reported as is, and no selective reporting } \\
\text { within studies. } \\
\text { Provide clear inclusion criteria to avoid selecting studies } \\
\text { according to whether their results reflected a favored conclusion. }\end{array}$ \\
\hline
\end{tabular}

FGD: Focus group discussion.

\section{Results and Discussions}

Based on the literature studies perspective, the majority of sources used in this study were selected from reputable sources: $84 \%$ of the references were from journals, $6 \%$ from student thesis or dissertation, $6 \%$ from conferences, and the rest came from book chapters and reports. Figure 4 visualizes the percentages of literature studies based on material types. Table 5 shows the numbers of references related to addiction based on publication type by year of publication. The five publication types identified were journal, thesis, conference, book, and report.

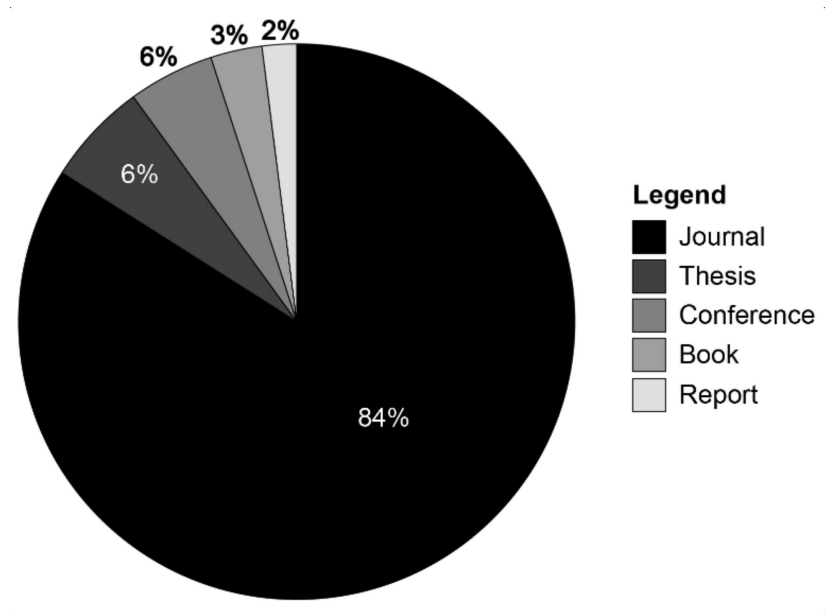

Figure 4. Distribution of related publications by material type.

This section provides answers to the research questions based on results obtained from the FGD sessions and extensive literature study. In order to better understand the data collected, the study was discussed based on research questions. 
Table 5. Count of identified publications by type and year.

\begin{tabular}{ccccccc}
\hline \multirow{2}{*}{ Year } & \multicolumn{5}{c}{ Type of Identified Publications } & \multirow{2}{*}{ Total } \\
\cline { 2 - 5 } & Journal & Thesis & Conference & Book & Report & \\
\hline 1996 & 1 & - & - & - & - & 1 \\
1999 & - & - & - & 1 & - & 1 \\
2002 & - & - & 1 & - & - & 1 \\
2003 & 2 & - & - & - & - & 2 \\
2004 & 1 & - & - & - & - & 1 \\
2005 & 3 & - & - & 1 & - & 4 \\
2006 & 4 & 2 & - & - & - & 6 \\
2007 & 3 & - & 1 & - & - & 4 \\
2008 & 6 & - & - & - & 1 & 7 \\
2009 & 5 & - & - & - & - & 5 \\
2010 & 5 & - & 1 & - & - & 6 \\
2011 & 4 & - & - & - & 1 & 5 \\
2012 & 7 & 2 & - & 2 & - & 11 \\
2013 & 7 & 1 & 1 & 1 & - & 10 \\
2014 & 11 & - & 1 & - & - & 12 \\
2015 & 20 & 2 & - & - & 1 & 23 \\
2016 & 19 & 1 & 3 & 1 & - & 24 \\
2017 & 31 & 3 & 1 & - & 1 & 36 \\
2018 & 19 & - & 1 & - & - & 20 \\
2019 & 12 & - & 1 & - & - & 13 \\
2020 & 4 & - & - & - & - & 4 \\
\hline Total & $\mathbf{1 6 4}$ & $\mathbf{1 1}$ & $\mathbf{1 1}$ & $\mathbf{6}$ & $\mathbf{4}$ & $\mathbf{1 9 6}$ \\
\hline & & & & & & \\
& & - & - & - & & \\
\end{tabular}

Data analysis was conducted using qualitative analysis based on the outcome of the FGD sessions. The medical experts and professional gamers team had extensively discussed the identified factors that influenced Malaysian adolescents in computer games. The identified factors of digital addiction and addiction components were verified during the FGD sessions. The DA relationship diagram includes the factors of DA, DA components, and DA assessment which are visualized using ATLAS. T.I. 8 software as in Figure 5.

Based on their knowledge and experience, this additional component was considered necessary from the medical perspective. The physical health component is also currently being used at a hospital to identify adolescents that are addicted to computer games. Table 6 presents six physical health consequences and their corresponding description of activities, which relate to the psychological and behavior DA factor.

\subsection{RQ1: Digital Addiction (DA)}

This subsection defines the term "addiction", "DA", explores the causes and impact of DA, as well as the effect of withdrawal of the addictive substance towards the addict.

\subsubsection{RQ1.0: What Is Addiction?}

Psychologically, addiction is an uncontrollable craving, often accompanied by a lack of control and denial of the negative effect caused by the behavior. Addiction is generally related to the use of addictive substances that are chemically induced, such as narcotics. There is a difference between addiction and abuse of a substance. In the case of addiction, the addict has an uncontrollable craving towards the addictive substance, while in the case of "abuse", an individual can restrain from the behavior of using the substance [10].

\subsubsection{RQ1.1: What Is DA?}

DA is a type of addiction towards technology that involves an extensive exposure of the human towards a machine, rather than addiction towards chemical substances [11]. Following this, addiction has quite a different meaning today. It no longer necessarily 
includes the behavior of the need for drugs, given the instances of computer games and gambling addiction.

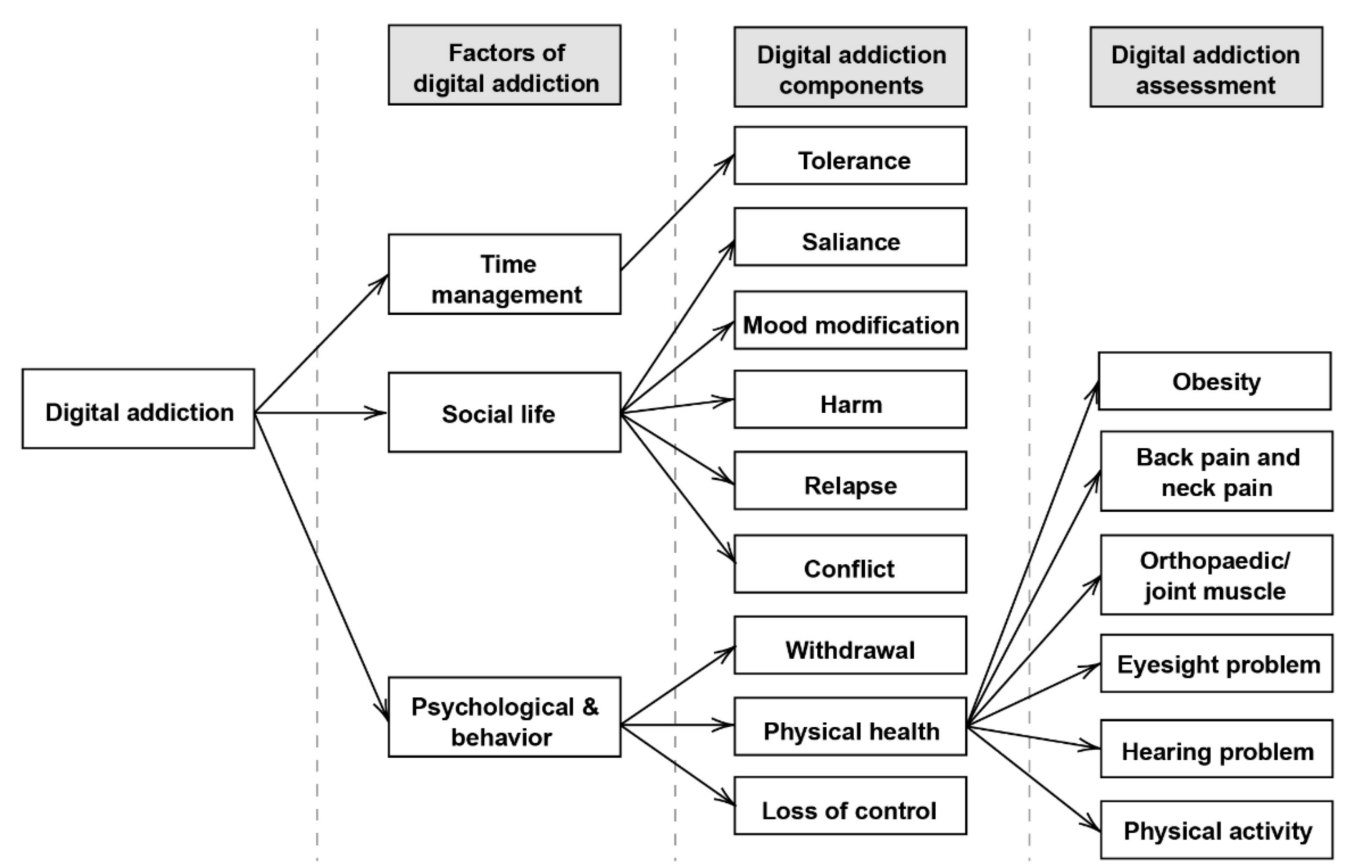

Figure 5. DA relationship diagram.

Table 6. The factor of DA, activity, and consequences on physical health.

\begin{tabular}{|c|c|c|}
\hline Factor of DA & Description of Activities & $\begin{array}{l}\text { Consequences on } \\
\text { Physical Health }\end{array}$ \\
\hline \multirow{6}{*}{$\begin{array}{l}\text { Psychological } \\
\text { behavior }\end{array}$} & $\begin{array}{c}\text { Playing computer games is a sedentary activity. Gamers tend to spend } \\
\text { time playing games indoors instead of performing outdoor activities. } \\
\text { Hence, they are prone to the risk of obesity, especially when they eat } \\
\text { while playing computer games. }\end{array}$ & Obesity \\
\hline & $\begin{array}{c}\text { Prolonged physical immobility will lead to muscle pain such as back } \\
\text { and neck pain. }\end{array}$ & Back pain and neck pain \\
\hline & $\begin{array}{l}\text { Using a mouse and keyboard for a long time causes muscle problems } \\
\text { in fingers and hands. }\end{array}$ & $\begin{array}{l}\text { Orthopaedic/ } \\
\text { joint muscle }\end{array}$ \\
\hline & $\begin{array}{c}\text { Having a long on-screen time can cause dry eyes and } \\
\text { eyesight problems. }\end{array}$ & $\begin{array}{l}\text { Eyesight } \\
\text { problem }\end{array}$ \\
\hline & $\begin{array}{c}\text { Continuous exposure to loud noise from headphones can reduce } \\
\text { hearing ability. }\end{array}$ & $\begin{array}{l}\text { Hearing } \\
\text { problem }\end{array}$ \\
\hline & $\begin{array}{l}\text { Computer gamers tend to have much less physical activity than other } \\
\text { people as they spend more time playing computer games in a room. }\end{array}$ & $\begin{array}{l}\text { Physical } \\
\text { inactivity }\end{array}$ \\
\hline
\end{tabular}

A study by Alrobai et al. [12] revealed that more players have invested extended hours playing on the computer as games evolve-and the addiction towards computer games has negative behavioral impacts on the time management, psychology, and social culture of the players. One of the most popular computer gaming concepts, known as MMOG, utilizes innovative technology with a three-dimensional perspective view and links multiple players over the Internet. This concept has attracted many adolescents to get involved, attached, and finally become addicted to playing computer games. However, the recovery process for DA is complex due to its relationship to human behavior and psychological is- 
sues. Tzavela et al. [13] have shown that no recognized clinical entity/diagnosis evaluation methods are available to diagnose DA in adolescents.

The Malaysian Communications and Multimedia Commission (MCMC) has reported that Malaysia had a population of 32.4 million in 2018 [14] — an increase of approximately 7.5 million from 21.7 million in 2016. On the other hand, Internet users' percentage has increased from 24.5 million users (76.9\%) in 2016 to 28.7 million (87.4\%) in 2018 [14]. Following this, it is reported that Malaysia e-Sport enthusiasts consist of more than 9.5 million, a number that is estimated to double in the upcoming year, and contribute revenue of 587 million U.S. dollars to the global game market [15]. For this reason, Malaysia is one of e-Sports' fastest rising regions. In comparison to the Malaysian e-Sports fans, there are 191 million e-Sports fans worldwide. E-Sports are known for immersive computer game competitions, which involve computer gaming skills and professionalization [16]. Recent research performed by MCMC with the collaboration of two private universities, which are Heriot-Watt University Malaysia and International Medical University, reported that from 795 respondents, the results showed that $89 \%$ of the respondents were diagnosed with Internet addiction. The results also showed that $60 \%$ of them demonstrated signs of anxiety, while $32 \%$ of them had major depression [17]. However, the research did not track specific Internet addiction types that may be covered (gambling, gaming, pornography, shopping, and others). Thus, this research study focuses specifically on DA. As previously reported [18], it is stated that DA is a serious issue that can cause the addicts to underperform in their social skills-leading to problems in thinking skills and emotions.

\subsubsection{RQ1.2: What Are the Causes of DA?}

DA covers a broad scope of activities, including addiction towards social media, computer games, chatting online, Internet addiction, as well as digital pornography addiction. Kapahi et al. [19] determined a few causes that lead to a type of DA which is Internet addiction. In his study, Kapahi et al. [19] noted that surfing adult websites may lead to Internet addiction. Adolescents may be exposed to adult websites when they surf game websites and websites that offer pirated contents that display pornography images. These adolescents may be triggered to explore more of the explicit content, and after a long time, they will become addicts. Another factor of addiction described by [19] is the excessive use of communication applications such as e-mail, messenger, or chat clients.

To understand the issue of computer game addiction, one must first understand the nature of the addiction. For instance, drug addiction is closely related to the misuse of medicine; alcohol addiction is caused by excessive drink consumption, and gambling addiction involves money and the players' finances. Social media, on the other hand, offers a platform for users to communicate with many people and to express themselves while being anonymous. Social media comes with benefits, but uncontrolled use of social media can cause DA. The users can spend long hours just scrolling pictures, watching videos, reading stories or posts, and do many more activities. These relations do show the pattern of Internet users with computer game addiction patterns [10,20,21].

Albeit being inspired by the traditional "pen and paper" role-playing games, levelling, which is a fundamental mechanism in computer games, has been found to be impactful on the interaction design of a computer game [22]. Differences in levels may be sufficient to reduce the cohesion of the guild and can become a substantial "churn rate" factor between the members. In previous research, Richard Bartle [23] proposed the taxonomy for computer game players into four categories as follows:

1. Achievers-always aim to achieve the goals set in the computer game (such as ranking higher in levels, reputations, and collection of treasure).

2. Explorers-players are primarily interested in the study of the environment of the simulated world (such as geography and physics).

3. Socializers-are interested in interacting with another player-either to impose themselves or to promote themselves. 
4. Killers-keep their interaction alive with other players-they keep communication and role-play active for teamwork.

\subsubsection{RQ1.3: How Does DA Impact an Addict?}

Research on the relationship between computer game addiction and violence, selfcontrol, and narcissistic behavior in South Korea [24] has shown a strong link between the obsession of computer gaming and negative behaviors. The study believes that high dependency on computer games has been linked to the interpersonal challenges faced by the addicts as well as their environmental and life pressures. In the context of social life, game addicts are usually obsessed with being online-with a gaming session lasting up to $20 \mathrm{~h}$, and they might spend between 40 and $80 \mathrm{~h}$ a week gaming. Most often, the sleep patterns of computer game addicts are affected due to having late-night gaming sessions online. The issue of computer game addiction deserves extra attention and awareness from various parties, as it has adverse effects on people's lives.

Playing computer games offers the players imagination, wonders, and the feeling of awe living in the game world. However, players of computer games can be labeled as antisocial, as they would prefer to spend most of their time gaming instead of socializing in real life with real people [25]. According to [26], computer games encourage group interactions and lead to a new form of social interaction by creating meaningful relationships with other players. The gamers can have many friends that have the same interest as them. Even though they do not meet in real life, it is enough for them to keep on playing for hours [19]. The addicts will be spending extra time communicating online instead of having social interactions in the real world.

Nevertheless, there is an argument against this statement for computer gamers who are looking for social connections, as they might face a problem in forming relationships in real life [27]. According to [28,29], IGD contributes to a poor quality of life (QOL) and cognitive dysfunction and is increasingly recognized as a social problem.

\subsubsection{RQ1.4: How Does the Withdrawal of the Addictive Substance Impact an Addict?}

Generally, the withdrawal of the addictive substance from an addict affects the psyche of the addict because the addict's dependence on the material is too strong $[10,21,25,28,30]$. Addicts are usually equipped with a variety of motivation strategies and show signs of computer game addiction (such as often having mood swings, conflicts, relapse, resistance, and salience). According to [31], the described psychological state of an addict is called "dependency". King et al. [22], in their study, provided an example of how aggressive and frustrated an addict could be when asked to avoid playing computer games. They reported that players who were unable to play computer games might suffer from extreme emotions including irritability, nervousness, or depression. Psychology has adopted terms in everyday use or terms used in other sciences and applied them in a more specific and technical sense. Players tend to follow their emotions and stop reasoning, thus displaying negative responses towards the people in their lives $[32,33]$.

\subsection{RQ2: Internet Gaming Disorder (IGD)}

This subsection explains IGD, causes of gaming addiction, the effect of excessive gaming, the possibility to cure IGD, DA factors and components affecting Malaysian adolescents, as well as the consequences of DA on adolescent's physical health.

\subsubsection{RQ2.0: What Is IGD?}

In the most recent edition of the Diagnostic and Statistical Manual of Mental Disorders (DSM), the American Psychiatric Association (APA) has published the definition of IGD [11]. Millions of people play computer games with no adverse effects on their lives, but still, a handful of gamers appear to have issues with a fair amount of gaming. Both DA and the abuse of computer games can correlate with an impact, and frequently, it will have harmful consequences, especially on physical health [34]. Unfavorable outcomes of DA associated 
with physical health are categorized into three factors, which include time management, social factors, and psychological factors related to emotion [35-37]. Lim et al. [28] have concluded that students who are addicted to Internet use have less incentive to learn activities, experience a plummeting in academic scores, skip more classes, and are more often placed on probation.

\subsubsection{RQ2.1: What Are the Causes of Computer Game Addiction?}

In a study by Do and Hong [38], two-thirds of the middle school students in G metropolitan city of Korea had computer game addiction problems. In the findings, Do and Hong reported that anxiety, ego-resilience, and gender had become the variables affecting DA [38] while in [35,39], reports have proven that negative comfort provided by the people around them also drove excessive gaming by provoking a sense of fear and curiosity among the players. Excessive computer gaming is also related to the online pornographic issue, which includes streaming through the web and sharing of adult-rated materials that can be used for trade purposes. Another reason for computer gaming addiction includes their need to express their feelings to other people online because those who are addicted may feel depressed, have suffered a loss of trust and might be isolated from others $[19,30]$.

\subsubsection{RQ2.2: What Are the Effects of Excessive Computer Gaming/IGD?}

The Internet provides several clear advantages for technological development if it is used with regulation. However, uncontrolled use of the Internet may lead to negative effects, such as depression and feeling moody when an addict is deprived of the resource. Uncontrolled use also may lead to an unhealthy lifestyle. Other effects from excessive use of the Internet include insomnia [3], lack of confidence skills [36], lack of social skills [36,40], and lack of responsibility [41]. Many researchers from various areas, such as computer sciences, psychology, and health, have conducted studies to investigate the impact of excessive use of the Internet and have suggested various solutions for the problem.

Human behavior is a term that describes the actions of an individual, and observing and understanding human behavior is a crucial part of psychology. In the case of a lack of social skills, computer gaming can gradually adjust the right brain, producing negative social feedback, which leads to reduced self-satisfaction in an individual when they interact with another individual. It is, therefore, clear that many children play computer games to a dangerous degree that puts the family, social, school, and psychological functions at risk [42]. Many who play computer games heavily are not only at risk of multiple adverse effects; they are also much more likely to play violent computer games [43]. Students with DA are easily influenced by emotions, less healthy, less creative, lost in thinking, have excessive feelings of self-sufficiency, are more open to experimenting, and tend to make their own decisions $[25,29,32]$. A few researchers $[25,26,43,44]$ have claimed that people who played more hours in a week have higher extraversion scores. In other words, a player who is reported to be extraverted spends more hours in games [45], and computer game addicts have difficulty in managing their time. The effects of failure in managing time for Internet use were mentioned by the previous researcher, such as decreased academic achievement [46].

A study on time management in [30] has presented results pertaining to students' Internet activities related to the Online Cognition Scale. As exposure to scholarly tasks such as academic material searches or scientific study declined, and the intensity of entertainmentbased Internet activities (such as chatting, web gaming, browsing for adult content, and listening to music) increased, the score on the Online Cognition Scale increased. Some research suggests that the amount of time children spend playing games is linked to attention deficit hyperactivity [47]. A recent study by [48] claimed that among 1491 students between the ages of 12-18, on average, those who played computer games spent 30 percent less time reading and 34 percent less time doing homework compared to students who did not play computer games. Young adults who had not done well at school tended to spend more time playing computer games, as they could experience a sense of superiority that 
allowed them to escape from the reality of having challenges at school. As a result, this will create possibilities that excessive gaming creates attention deficits, which in turn can lead to more mediocre school performance.

\subsubsection{RQ2.3: Is IGD Diagnosable and Curable?}

Psychologists and psychiatrists have recently studied computer games, and computer gaming is recognized as a diagnosable psychiatric disorder in the Fifth Edition of the DSM and has been reported in its appendix to promote more study. Research performed by [12] focuses on the correlation between treatment programs, social structures in rehabilitation communities, and the possibility of using software-based methods to intervene and curb DA problems.

In terms of quitting computer gaming, Sung, Nam and Hwang [49] reported that gamers have invested a great deal of their time in mastering computer games. Therefore, they tend to keep playing the computer game to avoid dealing with the bad feeling of letting go of the time invested in mastering the game. Next, they will reason to keep investing more time since the invested time will have been lost otherwise, without considering the negative effects of excessive gaming [49]. Therefore, computer gamers will encounter challenges to quit the habit of gaming, although IGD itself is considered curable.

\subsection{RQ3: What Are the Factors of DA in Computer Games Which Influence Malaysian Adolescents?}

As visualized in Figure 5, the three main factors of DA that have been identified are time management, social life, along with psychological and behavior, described as follows:

1. Time management-most computer gamers tend to spend extensive hours playing computer games, and they often spend late nights online with their gaming community. This situation raises concerns, as spending too much time on computer games affects the gamer's personal and professional life as a result.

2. Social life-social life is related to the relationship of the individual with family, friends, and their surrounding community. The five DA components related to the DA factor of social life will become a part of the personal lives of gamers. For instance, salience causes gamers to consider playing a game as an essential part of life. Mood modification lets gamers have mood swings and tend to spend more time playing games in their room. Relapse causes gaming behavior to become an addiction and keep repeating the gaming sessions. Harm causes gamers to think and behave aggressively with people around them, as aggression is a part of a computer gameMMOGs. Conflict is a situation where gamers challenge each other online, which, if brought into real-life, may cause harm and danger to other people.

3. Psychological and behavior-Physical and behavioral components of addiction include physical health, loss of control, and withdrawal. Physical health, as mentioned before, is a situation where gamers have issues with their health physically, such as neck and back pain. Loss of control includes mood swings, and withdrawal is the behavior changes of the addict when they are withdrawn from the addictive substance.

\subsection{RQ4: What Are the Components of DA in Computer Games Which Influence Malaysian Adolescents?}

According to the FGD group discussions, there are nine components of DA that have been identified in computer games. The addiction components include tolerance, salience, mood modification, harm, relapse, conflict, physical health, loss of control, and withdrawal. Table 1 in Appendix A has summarized the list of articles that discussed every DA factor. The physical health component has been suggested by the medical experts FGD, and this component is related to the psychological and behavior factors. Physical health refers to the physical condition of an individual who is a computer game addict, and this component is considered necessary and critical from the medical perspective (for example, some 
gamers may experience muscle or back pain). Figure 4 visualizes the relationship diagram suggested by the medical experts FGD.

The opportunity to access the entire Internet has allowed them to spend an endless amount of time interacting and playing computer games with people in the virtual world, causing teenagers to be addicted to computer gaming. Consequently, the addiction affects their social life and way of thinking, and their psychological actions towards others are impaired, leading to negative impacts such as poor time management. The sentiments of the player and the actual use of computer games are influenced by the experience of streaming, satisfaction, and engagement in computer games. Enjoyment and social influence become compelling evidence to assess actual gameplay [50].

Even though the Internet seems to bring advantages to adolescence, it also brings side effects if this matter is not handled appropriately. Many researchers have raised concerns when viewing the increasing statistics of Internet usage among adolescents. Research conducted by [51] studies the pattern of Internet usage and the type of users in university students in Malaysia. Another research performed by [52] studies the relationship between depression and DA. The results of these studies show that DA may lead to depression, and most of the addicts are male respondents because they spend a lot of time using the Internet when playing computer games. However, this relationship is still debatable among researchers $[5,10,53]$. An adolescent who is involved in computer game addiction would spend more time playing and connecting with people in the online world without limit, affecting their social skills, relationships with people around them, empathy, way of thinking or behaving in the real-world, and time management. Besides, most adolescents who are addicted to computer games may be driven by socioeconomic factors such as communicating on essential matters, obtaining sex-oriented materials, and making money.

Gaming within social media is not necessarily via explicit computer games forms, but rather through more subtle forms, including social gamification effect (such as likes, comments, and shares), competition (for badges and number of followers), exploration (of news and timelines), alternative reality (personas, avatars, and profiles), and many others. WHO has recently identified the symptoms of IGD, thus raising concern whether computer game companies need more regulation [2]. The call for regulation could include social media. Contrarily, only a few works have implemented software design to facilitate and combat DA problems through methods such as labeling the DA components and providing engineering requirements essential for digital well-being [12].

\subsection{RQ5: What Are the Consequences of Computer Game Addiction on Adolescent Physical Health?}

Medical experts have agreed that computer game addiction shows a significant impact on adolescent physical health, as follows:

1. Obesity-computer games addiction may cause adolescents to gain weight and become obese as gamers tend to continue eating while playing computer games, and at the same time, have no active physical movement to burn the added calories.

2. Back pain and neck pain-an extensive computer gaming period may cause gamers to have back and neck pain, as they tend to sit in the same position for hours while playing computer games.

3. Orthopaedic/joint muscle-Some might have orthopedic/joint problems, called gamer's thumb, or hand injuries due to spending an excessive amount of time using a mouse and keyboard.

4. Eyesight problems-excessive computer gaming and the use of screens negatively impact eyesight. A study by Lee et al. [54] has specifically focused on the effect of excessive computer gaming on binocular vision. The result suggests that excessive and constant gaming activity on computers causes both the weakening of visual functions and ocular and physical fatigue.

5. Hearing problems-computer gamers may also have reduced hearing ability, as they are used to listening to loud noises using their headphones. Some of the noises 
include loud sound effects, such as shooting, explosions, engines roaring, and other loud sound effects that are designed to immerse gamers into the gaming world.

6. Physical inactivity - computer gamers tend to spend more time playing computer games in a room instead of going for outdoor activities.

Many parents have come to meet medical experts for consultations for obtaining assistance regarding these matters. A few gamers have also refused to attend school as they became obsessed with gaming, and they sometimes show aggressive behavior to their family members.

\section{Discussion}

This research provides a comprehensive study of how DA has significantly impacted adolescents' physical health, in particularly Malaysian adolescents. The findings of this research indicate that the content of computer games has an impact on the physical health of adolescents, such as excessive gaming (online and offline). In addition, this research can be a guideline for computer game designers/developers to design computer games taking into consideration the physical health implications. Therefore, considering the digital wellbeing among adolescents by focusing on the digital wellbeing part, adolescents are expected to be able to gain control of their gaming habits, instead of falling victim as an addict. Secondly, the findings of this study help to identify measurable parameters that can be used by medical experts for early diagnosis. At the same time, it provides guidelines for doctors/psychiatrists to formulate a treatment plan to prevent patients from reaching a critical level of DA. Researchers and medical practitioners can further assess their subject study using six crucial DA assessments as measurement parameters for the design and development of diagnostic assessment tools.

\section{Conclusions}

In summary, this research has created a paradigm for future studies of the correlation between the impact of DA on adolescent physical health with the psychological and behavioral factors. These findings are considered robust and reliable for clinical conceptualization and understanding the source and impact of physical health among adolescents. This is based on data collected from the extensive literature study and analyzed through FGD. From the experts' point of view, this research illustrates the possible results of detecting DA among adolescents, incorporating innovations in diagnostic testing methods. Furthermore, the finding from this research can benefit in terms of creating a relational map of causes and impacts of DA as a whole, to come up with a control and treatment plan to prevent patients from reaching a critical level of DA.

Author Contributions: Conceptualization, N.A. and M.J.N.; methodology, M.M.M.S.; investigation, M.M.M.S.; writing—original draft preparation, M.M.M.S.; writing—review and editing, S.J.A.; visualization, M.M.M.S.; supervision, N.A. and S.J.A.; project administration, N.A. and M.J.N.; funding acquisition, N.A. All authors have read and agreed to the published version of the manuscript.

Funding: This research was funded by Yayasan Universiti Teknologi PETRONAS (YUTP) with a Cost Center 015LC0-277 for the Centre for Research in Data Science (CeRDaS).

Informed Consent Statement: Informed consent was obtained from all subjects involved in the study.

Conflicts of Interest: The authors declare no conflict of interest. The funders had no role in the design of the study; in the collection, analyses, or interpretation of data; in the writing of the manuscript, or in the decision to publish the results. 


\section{Appendix A}

Table A1. Included publications which discusses the DA factors.

\begin{tabular}{|c|c|c|c|c|}
\hline \multirow{2}{*}{ No. } & \multirow{2}{*}{ Authors } & \multicolumn{3}{|c|}{ Factors of DA } \\
\hline & & $\begin{array}{c}\text { Time } \\
\text { Management }\end{array}$ & $\begin{array}{c}\text { Social } \\
\text { Life }\end{array}$ & $\begin{array}{l}\text { Psychological } \\
\text { Behavior }\end{array}$ \\
\hline 1 & Ko CH, Yen JY, Chen CC, Chen SH, Yen CF. 2005 & $\mathrm{x}$ & $\mathrm{x}$ & $\mathrm{x}$ \\
\hline 2 & Chan PA, Rabinowitz T. 2006 & & $\mathrm{x}$ & $\mathrm{x}$ \\
\hline 3 & Kim EJ, Namkoong K, Ku T, Kim SJ. 2008 & & $\mathrm{x}$ & $\mathrm{x}$ \\
\hline 4 & Lemmens JS, Valknburg PM, Peter J. 2009 & $\mathrm{x}$ & $\mathrm{x}$ & $\mathrm{x}$ \\
\hline 5 & Lemmens JS, Valknburg PM, Peter J. 2009a & $\mathrm{x}$ & $\mathrm{x}$ & $\mathrm{x}$ \\
\hline 6 & Skoric MM, Teo LLC, Neo RL. 2009 & & $\mathrm{x}$ & $\mathrm{x}$ \\
\hline 7 & Rehbein F, Psych G, Kleimann M, Mediasci G, Mößle T. 2010 & $\mathrm{x}$ & $\mathrm{x}$ & $\mathrm{x}$ \\
\hline 8 & Thomas NJ, Martin FH. 2010 & $\mathrm{x}$ & $\mathrm{x}$ & $\mathrm{x}$ \\
\hline 9 & Rehbein F, Psych G, Kleimann M, Mediasci G, Mößle T. 2010a & $\mathrm{x}$ & $\mathrm{x}$ & $\mathrm{x}$ \\
\hline 10 & Thomas NJ, Martin FH. 2010a & $\mathrm{x}$ & $\mathrm{x}$ & $\mathrm{x}$ \\
\hline 11 & van Rooij AJ, Schoenmakers TM, van de Eijnden RJ, van de Mheen D. 2010 & & $\mathrm{x}$ & $\mathrm{x}$ \\
\hline 12 & Lemmens JS, Valknburg PM, Peter J, 2011 & $\mathrm{x}$ & $\mathrm{x}$ & $\mathrm{x}$ \\
\hline 13 & Lemmens JS, Valknburg PM, Peter J, 2011a & $\mathrm{x}$ & $\mathrm{x}$ & $\mathrm{x}$ \\
\hline 14 & Lemmens JS, Valknburg PM, Peter J, 2011b & $\mathrm{x}$ & $\mathrm{x}$ & $\mathrm{x}$ \\
\hline 15 & Van Rooij AJ, Schoenmakers TM, Van de Eijnden RJ, Van de Mheen D. 2011 & & $\mathrm{x}$ & $\mathrm{x}$ \\
\hline 16 & Kuss DJ, Griffiths MD. 2011 & $\mathrm{x}$ & & $\mathrm{x}$ \\
\hline 17 & Kuss DJ, Griffiths MD. 2011a & $\mathrm{x}$ & $\mathrm{x}$ & $\mathrm{x}$ \\
\hline 18 & Kuss DJ, Griffiths MD. 2012 & $\mathrm{x}$ & $\mathrm{x}$ & $\mathrm{x}$ \\
\hline 19 & Kuss DJ. 2013 & $\mathrm{x}$ & $\mathrm{x}$ & $\mathrm{x}$ \\
\hline 20 & King DL, Haagsma MC, Delfabbro PH, Gradisar M, Griffiths MD. 2013 & $\mathrm{x}$ & $\mathrm{x}$ & $\mathrm{x}$ \\
\hline 21 & Kuss DJ, Griffiths MD, Binder JF. 2013 & $\mathrm{x}$ & $\mathrm{x}$ & $\mathrm{x}$ \\
\hline 22 & Lee ZW, Cheung CM, Chan TK. 2015 & $\mathrm{x}$ & $\mathrm{x}$ & $\mathrm{x}$ \\
\hline 23 & Li W, O’Brien JE, Snyder SM, Howard MO. 2015 & $\mathrm{x}$ & $\mathrm{x}$ & $\mathrm{x}$ \\
\hline 24 & Brunborg GS, Hanss D, Mentzoni RA, Pallesen S. 2015 & $\mathrm{x}$ & $\mathrm{x}$ & $\mathrm{x}$ \\
\hline 25 & Andreassen CS. 2015 & $\mathrm{x}$ & $\mathrm{x}$ & $\mathrm{x}$ \\
\hline 26 & You S, Kim E, Lee D. 2017 & & $\mathrm{x}$ & \\
\hline 27 & Taylor T. 2016 & $\mathrm{x}$ & $\mathrm{x}$ & $\mathrm{x}$ \\
\hline 28 & Khan A, Muqtadir R. 2016 & $\mathrm{x}$ & $\mathrm{x}$ & $\mathrm{x}$ \\
\hline 29 & $\begin{array}{c}\text { Smohai M, Urbán R, Griffiths MD, Király O, Mirnics Z, Vargha A, } \\
\text { Demetrovics Z. } 2017\end{array}$ & $\mathrm{x}$ & $\mathrm{x}$ & $x$ \\
\hline 30 & Taylor T. 2016a & $\mathrm{x}$ & $\mathrm{x}$ & $\mathrm{x}$ \\
\hline 31 & King DL, Kaptsis D, Delfabbro PH, Gradisar M. 2016 & $\mathrm{x}$ & & $\mathrm{x}$ \\
\hline 32 & Lee WY. 2015 & $\mathrm{x}$ & $\mathrm{x}$ & $\mathrm{x}$ \\
\hline 33 & Monacis L, Palo VD, Griffiths MD, Sinatra M. 2016 & $\mathrm{x}$ & $\mathrm{x}$ & $\mathrm{x}$ \\
\hline 34 & King DL, Herd MC, Delfabbro PH. 2017 & $\mathrm{x}$ & & \\
\hline 35 & Kwok SW, Lee PH, Lee RL. 2017 & $\mathrm{x}$ & $\mathrm{x}$ & $\mathrm{x}$ \\
\hline 36 & Krossbakken E, Pallesen S, Molde H, Mentzoni RA, Finserås TR. 2017 & $\mathrm{x}$ & $\mathrm{x}$ & $\mathrm{x}$ \\
\hline 37 & Hawi NS, Samaha M. 2017 & $\mathrm{x}$ & $\mathrm{x}$ & $\mathrm{x}$ \\
\hline 38 & Kesici A, Tunç NF. 2018 & $\mathrm{x}$ & $\mathrm{x}$ & $\mathrm{x}$ \\
\hline
\end{tabular}




\section{References}

1. Caplan, S.; Williams, D.; Yee, N. Problematic Internet use and psychosocial well-being among MMO players. Comput. Hum. Behav. 2009, 25, 1312-1319. [CrossRef]

2. Ali, R. Digital Motivation, Digital Addiction and Responsibility Requirements. In Proceedings of the 20181 st International Workshop on Affective Computing for Requirements Engineering (AffectRE), Banff, AB, Canada, 21 August 2018.

3. Kuhu, P.A.; SarojVerma. Role of Internet Addiction in Mental Health Problems of College Students. Psychol. Behav. Sci. Int. J. 2017, 2, 555-591.

4. Shirinkam, M.S.; Shahsavarani, A.M.; Toroghi, L.M.; Mahmoodabadi, M.; Mohammadi, A.; Sattari, K. Internet addiction antecendants: Self-control as a predictor. Int. J. Med Res. Health Sci. 2016, 5, 115-143.

5. Yeap, J.A.L.; Ramayah, T.; Kurnia, S.; Halim, H.A.; Ahmad, N.H. The assessment of Internet addiction among university students: Some findings from a focus group. Teh. Vjesn. 2015, 22, 105-111. [CrossRef]

6. Santos, V.; Freire, R.; Zugliani, M.; Cirillo, P.; Santos, H.H.; Nardi, A.E.; King, A.L.S. Treatment outcomes in patients with Internet Addiction and anxiety. MedicalExpress 2017, 4. [CrossRef]

7. Keele, S. Guidelines for Performing Systematic Literature Reviews in Software Engineering; EBSE: Goyang City, Korea, 2007.

8. Ahmed, Y.A.; Ahmad, M.N.; Ahmad, N.; Zakaria, N.H. Social media for knowledge-sharing: A systematic literature review. Telemat. Inform. 2019, 37, 72-112. [CrossRef]

9. Moher, D.; Liberati, A.; Tetzlaff, J.; Altman, D.G.; Prisma Group. Preferred reporting items for systematic reviews and metaanalyses: The PRISMA statement. PLoS Med. 2009, 6, e1000097. [CrossRef]

10. Kuss, D.J.; Griffiths, M.D.; Pontes, H.M. Chaos and confusion in DSM-5 diagnosis of Internet Gaming Disorder: Issues, concerns, and recommendations for clarity in the field. J. Behav. Addict. 2017, 6, 103-109. [CrossRef]

11. Lehenbauer-Baum, M.; Fohringer, M. Towards classification criteria for Internet Gaming Disorder: Debunking differences between addiction and high engagement in a German sample of World of Warcraft players. Comput. Hum. Behav. 2015, 45, 345-351. [CrossRef]

12. Alrobai, A.; McAlaney, J.; Dogan, H.; Phalp, K.; Ali, R. Exploring the requirements and design of persuasive intervention technology to combat digital addiction. In Human-Centered and Error-Resilient Systems Development; Springer: Berlin/Heidelberg, Germany, 2016; pp. 130-150.

13. Tzavela, E.C.; Karakitsou, C.; Halapi, E.; Tsitsika, A.K. Adolescent digital profiles: A process-based typology of highly engaged Internet users. Comput. Hum. Behav. 2017, 69, 246-255. [CrossRef]

14. Internet Users Survey 2018; Suruhanjaya Komunikasi dan Multimedia Malaysia: Cyberjaya, Malaysia, 2018.

15. Aziz, A. RM10m Allocation for eSports a Great Start, Says MDec. 2018. Available online: https://www.theedgemarkets.com/ article/rm10m-allocation-esports-great-start-says-mdec (accessed on 22 October 2020).

16. Cunningham, G.B.; Fairley, S.; Ferkins, L.; Kerwin, S.; Lock, D.; Shaw, S.; Wicker, P. eSport: Construct specifications and implications for sport management. Sport Manag. Rev. 2018, 21, 1-6. [CrossRef]

17. Daily, T.S. Internet Addiction among M'sians Has Reached Alarming Rate: Jailani. 2017. Available online: https://www. thesundaily.my/archive/internet-addiction-among-msians-has-reached-alarming-rate-jailani-BUARCH512374 (accessed on 23 September 2018).

18. Daily, T.S. Internet Addiction Can Dominate Lives of Children: Rosmah. 2017. Available online: https://www.thesundaily.my/ archive/internet-addiction-can-dominate-lives-children-rosmah-LTARCH495320 (accessed on 22 July 2018).

19. Kapahi, A.; Ling, C.S.; Ramadass, S.; Abdullah, N. Internet addiction in Malaysia causes and effects. iBusiness 2013, 5, 33745. [CrossRef]

20. Pontes, H.M.; Griffiths, M.D. Internet addiction disorder and Internet gaming disorder are not the same. J. Addict. Res. Ther. 2014, $5, \mathrm{e} 124$.

21. Király, O.; Sleczka, P.; Pontes, H.M.; Urbán, R.; Griffiths, M.D.; Demetrovics, Z. Validation of the ten-item Internet Gaming Disorder Test (IGDT-10) and evaluation of the nine DSM-5 Internet Gaming Disorder criteria. Addict. Behav. 2017, 64, 253-260. [CrossRef]

22. King, D.L.; Kaptsis, D.; Delfabbro, P.H.; Gradisar, M. Craving for Internet games? Withdrawal symptoms from an 84-h abstinence from massively multiplayer online gaming. Comput. Hum. Behav. 2016, 62, 488-494. [CrossRef]

23. Bartle, R.A. Design principles. Mult. Soc. Asp. Digit. Gaming 2013, 3, 10.

24. Kwak, J.Y.; Kim, J.Y.; Yoon, Y.W. Effect of parental neglect on smartphone addiction in adolescents in South Korea. Child Abus. Negl. 2018, 77, 75-84. [CrossRef] [PubMed]

25. Lin, M.-P.; Wu, J.Y.-W.; You, J.; Hu, W.-H.; Yen, C.-F. Prevalence of Internet addiction and its risk and protective factors in a representative sample of senior high school students in Taiwan. J. Adolesc. 2018, 62, 38-46. [CrossRef]

26. Jansz, J.; Martens, L. Gaming at a LAN event: The social context of playing video games. New Media Soc. 2005, 7, 333-355. [CrossRef]

27. Peters, C.S.; Malesky, L.A., Jr. Problematic usage among highly-engaged players of massively multiplayer online role playing games. Cyberpsychol. Behav. 2008, 11, 481-484. [CrossRef] [PubMed]

28. Lim, J.-A.; Lee, J.; Jung, H.Y.; Sohn, B.K.; Choi, S.; Kim, Y.J.; Kim, D.; Choi, J.-S. Changes of quality of life and cognitive function in individuals with Internet Gaming Disorder: A 6-month follow-up. Medicine 2016, 95, e5695. [CrossRef] 
29. Mo, P.K.H.; Chan, V.W.Y.; Chan, S.W.; Lau, J.T.F. The role of social support on emotion dysregulation and Internet addiction among Chinese adolescents: A structural equation model. Addict. Behav. 2018, 82, 86-93. [CrossRef]

30. Latif, R.A.; Aziz, N.A.; Jalil, M.T.A. Impact of online games among undergraduate students. In Proceedings of the 6th International Conference on Computing Informatics, Cheonan, Korea, 25-27 April 2017; pp. 523-532.

31. Rho, M.J.; Jeong, J.-E.; Chun, J.-W.; Cho, H.; Jung, J.; Choi, Y.; Kim, D.J. Predictors and patterns of problematic \{Internet\} game use using a decision tree model. J. Behav. Addict. 2016, 5, 500-509. [CrossRef]

32. Chang, S.-L.; Chen, C.-Y. An exploration of the tendency to online game addiction due to user's liking of design features. Asian J. Health Inf. Sci. 2008, 3, 38-51.

33. Roh, D.; Bhang, S.-Y.; Choi, J.-S.; Kweon, Y.S.; Lee, S.-K.; Potenza, M.N. The validation of Implicit Association Test measures for smartphone and Internet addiction in at-risk children and adolescents. J. Behav. Addict. 2018, 7, 79-87. [CrossRef] [PubMed]

34. Khazaal, Y.; Billieux, J.; Thorens, G.; Khan, R.; Louati, Y.; Scarlatti, E.; Theintz, F.; Lederrey, J.; Van Der Linden, M.; Zullino, D. French validation of the Internet addiction test. Cyberpsychol. Behav. 2008, 11, 703-706. [CrossRef]

35. Muhaimin, M.; Aziz, N.; Ariffin, M. Problematic of Massively Multiplayer Online Game Addiction in Malaysia. In Proceedings of the International Conference of Reliable Information and Communication Technology, Kuala Lumpur, Malaysia, 23-24 June 2018; pp. 749-760.

36. Aziz, N.; Iida, H.; Ariffin, M.; Akhir, E.A.P.; Sugathan, S.K. Massively Multiplayer Online Game (MMOG) impact towards Malaysian youth's time management, social life and psychology. Adv. Sci. Lett. 2018, 24, 1754-1757. [CrossRef]

37. Wan, C.-S.; Chiou, W.-B. Why are adolescents addicted to online gaming? An interview study in Taiwan. Cyberpsychol. Behav. 2006, 9, 762-766. [CrossRef] [PubMed]

38. Do, E.Y.; Hong, Y.R. Factors Influencing Internet Game Addiction in Middle School Students. Med. Leg. Update 2020, 20, 2167-2172.

39. Adiele, I.; Olatokun, W. Prevalence and determinants of Internet addiction among adolescents. Comput. Hum. Behav. 2014, 31, 100-110. [CrossRef]

40. Jamaluddin, H.; Ahmad, Z.; Zainal, N. Exploratory Study on Internet Addiction among Varsity Students in Malaysia. In Proceedings of the International Conference on e-Commerce, e-Administration, e-Society, e-Education, and e-Technology (e-CASE \&e-TECH 2011), Tokyo, Japan, 19-21 January 2011.

41. Shubnikova, E.G.; Khuziakhmetov, A.N.; Khanolainen, D.P. Internet-addiction of adolescents: Diagnostic problems and pedagogical prevention in the educational environment. Eur. J. Math. Sci. Technol. Educ. 2017, 13, 5261-5271. [CrossRef]

42. Son, D.T.; Yasuoka, J.; Poudel, K.C.; Otsuka, K.; Jimba, M. Massively multiplayer online role-playing games (MMORPG): Association between its addiction, self-control and mental disorders among young people in Vietnam. Int. J. Soc. Psychiatry 2013, 59, 570-577. [CrossRef]

43. Krossbakken, E.; Pallesen, S.; Molde, H.; Mentzoni, R.A.; Finserås, T.R. Not good enough? Further comments to the wording, meaning, and the conceptualization of Internet Gaming Disorder: Commentary on: Chaos and confusion in DSM-5 diagnosis of Internet Gaming Disorder: Issues, concerns, and recommendations for clarit. J. Behav. Addict. 2017, 6, 114-117. [CrossRef] [PubMed]

44. Yee, N. Motivations for Play in Online Games. Cyberpsychol. Behav. 2006, 9, 772-775. [CrossRef]

45. King, D.L.; Herd, M.C.E.; Delfabbro, P.H. Motivational components of tolerance in Internet Gaming Disorder. Comput. Hum. Behav. 2018, 78, 133-141. [CrossRef]

46. Chou, T.-J.; Ting, C.-C. The role of flow experience in cyber-game addiction. Cyberpsychol. Behav. 2003, 6, 663-675. [CrossRef]

47. Sim, T.; Gentile, D.A.; Bricolo, F.; Serpelloni, G.; Gulamoydeen, F. A conceptual review of research on the pathological use of computers, video games, and the Internet. Int. J. Ment. Health Addict. 2012, 10, 748-769. [CrossRef]

48. Allen, J.; Anderson, C.A. Satisfaction and frustration of basic psychological needs in the real world and in video games predict \{Internet Gaming Disorder\} scores and well-being. Comput. Hum. Behav. 2018, 84, 220-229. [CrossRef]

49. Sung, Y.; Nam, T.-H.; Hwang, M.H. Attachment style, stressful events, and Internet gaming addiction in Korean university students. Personal. Individ. Differ. 2020, 154, 109724. [CrossRef]

50. Alzahrani, A.I.; Mahmud, I.; Ramayah, T.; Alfarraj, O.; Alalwan, N. Extending the theory of planned behavior (TPB) to explain online game playing among Malaysian undergraduate students. Telemat. Inform. 2017, 34, 239-251. [CrossRef]

51. Norliah, K.; Safiah, S.; Izharrudin, Z.; Kamalrudin, M.; Hassan, M.A.; Mohamed, S. Internet Usage Pattern and Types of \{Internet\} Users among Malaysian University Students. J. Eng. Appl. Sci. 2017, 12, 1433-1439.

52. Othman, Z.; Lee, C.W. Internet addiction and depression among college students in Malaysia. Int. Med, J. 2017, 24, 447-450.

53. Poli, R. Internet addiction update: Diagnostic criteria, assessment and prevalence. Neuropsychiatry 2017, 7, 4-8. [CrossRef]

54. Lee, J.-W.; Cho, H.G.; Moon, B.-Y.; Kim, S.-Y.; Yu, D.-S. Effects of prolonged continuous computer gaming on physical and ocular symptoms and binocular vision functions in young healthy individuals. Peer] 2019, 7, e7050. [CrossRef] [PubMed] 